\title{
A Practitioner's Viewpoint: Effectively Representing an Incompetent Client in Custody Proceedings
}

\author{
Evon M. Spangler and Perry M. de Stefano, Member, IEDRC
}

\begin{abstract}
The court must consider the physical and mental health of all individuals involved in awarding custody. However, an individual's mental health can affect the individual's ability to participate in the case. That is, in some cases, the individual's mental health has so greatly affected the individual's abilities that he or she is not competent to participate in the proceeding. In that circumstance, the legal practitioner is confronted with legal and ethical issues. Both the federal and state constitutions recognize a party's constitutional right to participate in a legal proceeding determining the custody of her child. In Minnesota, under Rule 1.14, an attorney may take reasonably protective action, and seek the appointment of a guardian ad litem, conservator, or guardian if the attorney believes that a client with diminished capacity is at risk of substantial physical, financial, or other harm unless action is taken and that the client cannot adequately act in her own interests. This paper will explore the topic through two custody case studies one in a divorce proceeding and the other in a paternity proceeding, and the attorney's use of forensic experts to assist us in advocating for our incompetent clients in custody cases.
\end{abstract}

Index Terms-Custody, due process, ethics, mental competency.

\section{INTRODUCTION}

Representing a client in a custody proceeding is often a complex, complicated endeavor for an attorney. This is particularly due to the nature of contested custody cases which are often volatile and high conflict. However, the complexity of a contested custody proceeding increases substantially when an attorney's client is incompetent due to the inability of the client to assist counsel in defending the case. Moreover, the client has constitutional due process rights in cases involving the custody of a child. Balancing the wishes of a client who is incompetent with his or her due process rights is extremely challenging. The challenges increase due to the numerous practical and ethical issues that an attorney must take into consideration and analyze in a case where an attorney believes that a client is incompetent.

This article provides a practitioner's viewpoint on the situation in which an attorney is faced with moral and professional dilemmas while representing a client the attorney believes is incompetent. There are numerous laws and rules that intersect with each other, including statutory laws, constitutional laws, and the rules of court. Part II provides an overview of custody law outlining Minnesota's

Manuscript received April 3, 2013; revised June 25, 2013. This work was supported in part by Spangler and de Stefano, PLLP.

The authors are with Spangler and de Stefano, PLLP, St. Paul, MN 55105, USA perry_destefano@qwestoffice.net). "best interests of the child" standard for dealing with custody disputes, and an overview of constitutional law as it applies to custody proceedings. The Minnesota "best interests of the child" standard provides no guidance to an attorney in how to assist a client who is incompetent, but rather the attorney must look further to determine how best to represent a client who is incompetent. Furthermore, an attorney who represents a client who is incompetent must take into consideration the client's constitutional rights to due process when custody of a child is at stake. In addition, Part II explores two specific case studies involving incompetent clients in custody proceedings. The two case studies show two different circumstances in how the attorney determined that a client was incompetent, and two different methods in how the attorney obtained a professional medical opinion that the client was incompetent. The first case study involves a mother who had a post partum psychosis that resulted in the mother being hospitalized in the psychiatric ward. This case study was further complicated by the mother's refusal to accept her mental health diagnosis, and as a result, the mother's refusal to follow the recommendations of the mental health professionals, which included medication being prescribed for the mother. As a result of the mother's issues, she lacked insight and judgment, and had difficulty understanding why a court had awarded temporary custody to the father and limited her parenting time to supervised time. The second case study involves a father who had cognitive impairments that had never been properly diagnosed or treated. As a result, the father was able to present well to others as he had developed coping mechanisms throughout his life to overcome his impairments so that others would not be able to determine that he had cognitive impairments. This case study was complicated because of the lack of a proper diagnosis and because the father's coping mechanisms made it more difficult for professionals to determine his cognitive abilities.

\section{THE INTERSECTION OF CUSTODY DisPUTES AND AN INCOMPETENT PARENT'S RIGHT TO PARTICIPATE IN LEGAL PROCEEDINGS}

Determining which parent has custody of a child is within the state court's jurisdiction. However, a parent has a constitutional due process right to participate in the custody proceeding as outlined in both federal and state law [1]. This constitutional due process right is not waived if a parent is incompetent [2]. In fact, the duty of an attorney to ensure that an incompetent parent has the right to participate in custody proceedings is amplified [3]. Even so, parental participation varies depending on the circumstances and severity of the 
parent's diminished capacity. The intersection of custody law and an incompetent client's constitutional right to participate in the custody proceeding, and the complexities that naturally flow from this intersection creates difficult challenges for the attorney.

\section{A. Overview of Custody Law}

There has been an increase in the number of single-parent households in the United States [4]. In Minnesota, initial custody proceedings generally occur through dissolution of marriage or a paternity action [5]. If the parents involved in the custody dispute are unable to agree on a custody plan, the state trial court [6] becomes the pivotal arena for resolving the dispute [7]. With a trial court having considerable discretion pertaining to custody factors [8], the appellate level review is limited to a finding of whether the trial court abused its discretion [9]. A heightened standard for review makes a successful appeal a difficult, if not insurmountable, barrier [10].

In custody proceedings, the "best interests of the child" standard is used [11]. The thirteen factors encompassed in "the best interests of the child" include: the wishes of the child's parent or parents as to custody; the reasonable preference of the child (if the child is of sufficient age); the child's primary caretaker; the relationship between each parent and the child; the interaction and interrelationship of the child with a parent or parents, siblings and any other person who may significantly affect the child's best interests; the child's adjustment to home, school, and community; the length of time the child has lived in a stable, satisfactory environment and the desirability of maintaining continuity; the permanence, as a family unit, of the existing or proposed custodial home; the mental and physical health of all individuals involved (except that a disability, as defined in Minn. Stat. 363A.03, of a proposed custodian or the child shall not be determinative of the custody of the child, unless the proposed custodial arrangement is not in the best interest of the child); the capacity and disposition of the parties to give the child love, affection, and guidance, and to continue educating and raising the child in the child's culture and religion or creed, if any; the child's cultural background; the effect on the child of the actions of an abuser, if related to domestic abuse, as defined in section 518B.01, that has occurred between the parents or between a parent and another individual, whether or not the individual alleged to have committed domestic abuse is or ever was a family or household member of the parent; and except in cases in which a finding of domestic abuse as defined in section 518B.01 has been made, the disposition of each parent to encourage and permit frequent and continuing contact by the other parent with the child [12]. Far from clear, the standard has been described as vague and indeterminate due to the varying determinations among states' methods in deciding the custody arrangement [13]. Furthermore, even when the evidence supports a different conclusion, the trial court's custody determination will not be disturbed if the evidence supports the trial court's conclusions [14].

In Minnesota, the best interests of the child standard encompasses thirteen factors that the court must consider and evaluate in making an initial custody award[15], and an additional four factors that the court must consider and evaluate if either party is seeking a joint custody award[16]. The additional four factors are as follows: "the ability of parents to cooperate in the rearing of their children; methods for resolving disputes regarding any major decision concerning the life of the child, and the parents' willingness to use those methods; whether it would be detrimental to the child if one parent were to have sole authority over the child's upbringing; and whether domestic abuse, as defined in section 518B.01, has occurred between the parents." These factors, however, are not exclusive [17]. In fact, even when the trial court includes unsupported findings, so long as the findings necessary for a legal conclusion are adequately supported, the district court's inclusion of other unsupported findings is harmless error [18]. Among the thirteen factors no one factor may be used to the exclusion of the others [19]. Also, the court is specifically prohibited from considering conduct of the parent who is seeking custody that does not affect the parent's relationship to the child.

While all of the "best interests" factors are rather arbitrary, perhaps one of the most discretionary factors relates to the mental and physical health of the individuals involved in the proceeding [20]. The court must consider and evaluate "the mental and physical health of all individuals involved; except that a disability, as defined in section 363A.03, of a proposed custodian or the child shall not be determinative of the custody of the child, unless the proposed custodial arrangement is not in the best interest of the child [20]." Minnesota law defines a disability as "any condition or characteristic that renders a person a disabled person [21]." A disabled person is "any person who (1) has a physical, sensory, or mental impairment which materially limits one or more major life activities; (2) has a record of such impairment; or (3) is regarded as having such an impairment." However, Minnesota courts have struggled in defining the applicability of the "disability" custody factor [22].

1) Minnesota case law: a contrast in defining "the best interests of the child" as it relates to a parent's mental or physical health.

In the Schumm case, the parties were the parents of two children who were 12 and 9 years old [23]. The mother had a major mood disorder and a vascular headaches history, both of which interfered with her ability to function. At times she slurred her speech, fell asleep at unusual times, and dropped lighted cigarettes on the floor. However, it is unclear from the decision whether her behaviors were the result of her major mood disorder, her vascular headaches or from a noted potential chemical dependency problem that was also discussed in the decision. A custody evaluator recommended that the father have physical custody, and the trial court awarded physical custody to the father.

The mother argued on appeal that the findings were not adequate and she focused on Minn. Stat. $\S 518.18$, subd. 1(a) (9), which at that time was new language. The new language "requires consideration, if relevant, of 'the mental and physical health of all individuals involved' and states that 'a disability, as defined in section 363.01, of a proposed custodian...shall not be determinative of the custody of the 
child, unless the proposed custodial arrangement is not in the best interest of the child." The court found that the mother's mental health problems raised a prima facie case of disability as she was unable to work for several years due to her depression. The court noted that the trial court made findings on the mother's "major mood disorder, her positive response to lithium, and her vascular headaches, which can last two to three days and prevent her from most activity" and that she was "under the care of a psychiatrist, that she was improving with treatment and had a good prognosis, and that she would need ongoing treatment to maintain improvement [24]." Furthermore, the court noted that the trial court "indicated that there have been occasions when the two children 'were their own caretakers as well as their mother's"' and that there were several examples of the mother's inability to care for her children, and the children's "concern for both their own safety and their mother's health and safety." The trial court's award of physical custody to the father was upheld as the court found the trial court had "properly considered the disability only to the extent it was relevant to the best interests of the children."

The result in Schumm is very different than the result in Meyer [25]. In Meyer the parties had an eight year old son. The father filed for divorce in 1983. However, in the 1970's, the father was a "practicing alcoholic," in 1980 he received treatment, and thereafter he was a "recovering alcoholic." During the 1970's when the father was a "practicing alcoholic," the mother was the primary parent, and "demonstrated the strength and ability to keep things together." In 1980, the mother started to have mental health problems, and from 1980 - 1984 she had the following diagnoses at different times: brief reactive psychosis, personality disorder of the schizotypal type, major affective disorder with psychotic features, major depression, personally disorder, schizoid type with significant elements of situational stress and associated depression, and schizophrenia-paranoid type. During this time period, the mother was hospitalized six times. Her hospitalizations (in order from least recent to most recent) consisted of being hospitalized for one day, nine days, 19 days, eight days, 26 days and 13 days. At trial she exhibited symptoms of her mental illness.

The father testified at trial that the mother threatened to commit suicide if the child was not allowed to live with her after she moved out in 1983. He testified that he did not object to the mother having liberal parenting time with their son, but he believed her condition was worsening. The trial court found "that both [parents] are presently fit and proper persons to have the care, custody and control of their child...; However, at the present time [child] best interests are served by continued residence with [mother] and liberal visitation with [father]." The trial court found that the mother "continues to suffer from a psychiatric disorder diagnosed as schizophrenia paranoid type," but she recognizes her need for continued treatment and medication. The court appeared to give great weight to the testimony of experts regarding the mother's treatment and her willingness to change her behavior. The trial court further found that if the mother continued her treatment and medication "she can function normally, handle the responsibilities of a parent, obtain an education, and become employable." The trial court granted custody of the child to the mother with "liberal and structured" parenting time for the father.

The appellate court affirmed the award of custody to the mother stating that the evidence relied upon shows that although the mother "continues to have mental problems, her behavior is neither dangerous nor detrimental to [child]." However, the court did find that the trial court did not provide for "sufficient means" for the father to "be able to ascertain whether [mother] is continuing to provide adequate care for [child]." The trial court had allowed the father to have access to the child's counseling records as the mother was ordered to enroll their son in a counseling program, but the appellate court found that requirement did not go far enough and ordered the trial court to make more "rigid safeguards with respect to [father's] ability to closely monitor [mother's] condition while she has custody of [child]."

The weight that the court placed on the father's alcoholism in its actual analysis of the custody determination is unclear. However, it appears that the father's alcoholism was no longer a concern, and there was no evidence that the father's alcoholism, which it appears was in remission, impacted his ability to raise his child. Even if the court did not believe that the father was disabled or perceived as disabled, the law requires that if a mental or physical disability is present in a custody case that the court must consider it only to the extent that it would have an impact on the ability of the parent to raise the children [24]. The court clearly had concerns about the mother's ability to raise the child because it specifically provided provisions for the father to monitor the mother's behaviors. Such a result places an untenable burden on the father, and the court's analysis failed to adequately consider the best interests standard.

\section{B. Overview of Constitutional Law as it Applies to Custody Proceedings}

The family unit has been traditionally protected under the Constitution. The family unit is defined as "a unit with broad parental authority over minor children [26]." The concept of the "family unit" as a "natural and fundamental...unit of society...entitled to protection by society and the State" is well-recognized among international treaties and laws [27]. If life, liberty, or property is at stake, procedural due process requires notice and an opportunity to be heard [28]. Both the notice and opportunity to be heard must be "provided at a meaningful time and in a meaningful manner" to satisfy the constitutional guarantee [29]. The U.S. Supreme Court has recognized a protected liberty interest "of parents in the care, custody and control of their children [as] perhaps the oldest of the fundamental liberty interests....[30]". The liberty interest is more important than any property interest[31].

The U.S. Supreme Court has carved out exceptions to the fundamental liberty interest a parent has depending on the nature of the relationship the parent has to a child. An unwed biological father has a liberty interest to his child even though he is not wed to the mother[32]. The liberty interest of a biological parent stems from the biological connection between the parent and the child [33]. However, a biological relationship does not guarantee the permanent parental rights of an unwed biological father [34]. Rather, "[t]he 
significance of the biological connection is that it offers the natural father an opportunity that no other male possesses to develop a relationship with his offspring [35]." If the biological father fails to come forward to "demonstrate [ ] a full commitment to the responsibilities of parenthood," the opportunity to do so is lost. Therefore, even in a case where the mother thwarted a future relationship between the biological father and the child, including refusing to accept financial support from the father who was not married to the mother, the U.S. Supreme Court held that the onus is on the biological father to pursue legal avenues available to him to establish a relationship with the child. Therefore, the biological father's attempts were meaningless when he failed to take advantage of the remedy of filing with the putative father's registry to receive notice of the adoption of his biological child. The U.S. Supreme Court has held that there is no deprivation of a biological parent's due process or equal protection rights when the father fails to assert his rights and establish a relationship with his child. Contrarily, when the parties are married, the parents have similarly situated custodial relationships with the child that automatically triggers the due process and equal protection clauses of the US Constitution.

\section{1) Civil commitment of a parent during the custody proceedings}

Under the Minnesota Civil Commitment Act, the State, with some exceptions, can commit an individual who is mentally ill [36]. An individual who is deemed civilly committed as mentally ill remains under the authority of the civil commitment court for the period of the commitment [37]. However, the mere fact that a mentally ill parent is civilly committed by the civil commitment court does not automatically mean that the parent is unfit to have custody of her child [38]. A civil commitment order should provide notice to the attorney that the parent may have diminished capacity. Often, people mistake an order for civil commitment to mean that a person who is civilly committed is incompetent. The facts that resulted in the civil commitment of the parent will guide the attorney to make an assessment as to the parent's capacity. Often, people mistake an order for civil commitment to mean that a parent has relinquished custody rights. However, neither the civil commitment of a parent nor the failure of the parent to take actual physical possession [39] of a child is automatically, by operation of law, a change in custody [40].

Generally, the civil commitment of a parent would go to the custody factor of a parent's mental condition [41]. However, if the parent has a "disability [42]," a parent's disability does not automatically mean that a parent will not be awarded custody. The overriding consideration is whether or not the proposed custodial arrangement is not in the child's best interests if the parent has a "disability."

The state court intervenes and decides what is in the best interests of the minor child if the parents are involved in a custody dispute, and are unable to come to a resolution [43]. However, because of this well-protected, fundamental right, a parent in a contested custody case has both a federal and state recognized constitutional right to participate as a party in a legal proceeding determining the custody of her child [44]. "The failure to grant a parent an opportunity to be heard on custody issues is a denial of equal protection and due process." Therefore, if the parent is under a civil commitment order and is confined to a hospital, treatment facility, or other institution the attorney should request a continuance of a court hearing in a custody proceeding.

\section{2) Brittnay nelson's case study}

A parent's mental health can change even when there aren't any indicators previously that the parent suffers from a mental illness. Brittnay Nelson was an "academic all star" all of her life. She had two master's degrees, and a Ph.D. She loved to learn and was constantly educating herself to become better at what she did and was committed to reaching the top. She learned quickly and engaged in intellectually stimulating conversations and could hold her own in any type of conversation. Ms. Nelson was loved by everyone; she had that zest for life that caused the world around her to sparkle after she touched it. She was going places and she had great dreams to one day be a Congresswoman. She dreamed of having it all - a husband, a family, and a career. Ms. Nelson fell in love during college and she married her college sweetheart. She and her husband were considered to be the "it" couple. They complimented each other and were eager to achieve their dreams together. Ms. Nelson then became pregnant with her first child. She loved everything about being pregnant, and although she would have been happy to have a boy or a girl, she was secretly pleased when she had a daughter. Unfortunately, within a couple of months after her daughter's birth, it became clear that Ms. Nelson had more than the typical "baby blues." Her mental health quickly spiraled out of control, and she started exhibiting symptoms of mania. Then when she started having a psychotic breakdown, Ms. Nelson was hospitalized in the psychiatric ward and she was civilly committed. Ms. Nelson refused to believe that there was anything wrong with her, and she lashed out at her husband and her family when they attempted to help her. She insisted that she was "just fine," and it was everyone else who was at fault for the situation that she was in. She was prescribed medications, and she would pretend to take her medications because she knew that everyone wanted her to take the medications, but she refused to believe that she needed medication.

Her husband filed for divorce, and requested sole custody of the child, which he was granted on a temporary basis. Ms. Nelson was granted supervised parenting time of her child on a temporary basis. She was devastated about the loss of her child and railed against those around her. During the two years that the case progressed slowly through the court process, Ms. Nelson was hospitalized an additional time and she was civilly committed again. It was baffling as to why Ms. Nelson was not getting "better." She insisted that she was taking her medication. In fact, she had a case manager watch her every day to make sure that she was taking her medication. However, Ms. Nelson was not getting better. Then in one of her therapy sessions, she told her therapist "a secret." The secret she stated was that "I'm not really taking my medications."

Ms. Nelson, a charismatic, professional woman, was devastated that she had lost temporary custody of her child, and was supervised while taking care of her child. She 
refused to believe that it was in her child's best interest that she had supervised parenting time. She insisted that there was nothing wrong with her and that her constitutional rights were being violated by having to be supervised while the child was in her care.

The diagnosis for Ms. Nelson was "bi-polar disorder." It was extremely difficult for Ms. Nelson to accept her diagnosis of "bi-polar disorder." In fact, she refused to believe that she had any mental health issues, especially not "bi-polar disorder" as she was "not crazy." Thus, she refused to follow her psychiatrist's advice, and did not take her medication. She insisted that as a professional woman with three advanced degrees, there was no way that she could have "bi-polar disorder," and that all of the doctors and the "system" were conspiring against her. Unfortunately, Ms. Nelson's refusal to accept her diagnosis was keeping her from stabilizing, and until she had stabilized, the court was not going to change the custody or parenting time order.

A trial was finally set in the matter. The trial, when it got set, was at a good time for Ms. Nelson because it appeared that Ms. Nelson was actually taking her medication and was stabilizing. However, as had happened before in her case right before a court hearing, one month prior to the trial date, Ms. Nelson was again a resident of the psychiatric ward after having a complete psychotic breakdown. Ms. Nelson's attorney visited her in the hospital, and it was clear from her "conversation" with Ms. Nelson that Ms. Nelson was not competent. Thus, the attorney obtained a letter from Ms. Nelson's physician stating that Ms. Nelson was incompetent, and the attorney then requested a continuance of the trial. Ms Nelson's husband objected to the continuance, and insisted that Ms. Nelson's mother could serve as guardian ad litem, and the case could proceed without further delay. However, counsel for Ms. Nelson argued that Ms. Nelson had a constitutional right to participate in child custody proceedings, and therefore, urged the court to delay the proceeding by three months for a determination then as to Ms. Nelson's competency. Counsel for Ms. Nelson also argued that the court should not appoint a guardian ad litem at this time, and rather the court should order the least restrictive alternative, which was a delay in the proceeding. The court agreed, and three months later, Ms. Nelson was deemed competent by a court appointed psychiatrist, and the proceeding continued.

\section{3) Determining if a client is incompetent}

When a client does not understand a particular point that an attorney is making or does not understand the explanation that is provided, the attorney adjusts how he or she is explaining the point to the client until the client understands the particular point. In this type of scenario, the attorney is not concerned that the client does not have the ability to understand the entire proceedings, but rather, due to the nature of the "words of art" an attorney naturally uses, the client simply needs an additional explanation because they have never heard that term or concept before. However, sometimes, not only does the client not understand a particular point no matter how many different and varied ways it is explained, the client does not have a grasp of the entire proceeding. Determining whether a client is incompetent is not an exact science.

Professional rules of conduct require a lawyer to "provide competent representation to a client [45]" regardless of their competency. An attorney must also "explain a matter to the extent reasonably necessary to permit the client to make informed decisions." However, difficulties and unfamiliar situations can quickly arise when the attorney is unable to explain even basic legal matters to their client due to their client's diminished mental capacity. With an already dim line becoming even more evasive, a lawyer has an obligation to, "as far as reasonably possible, maintain a normal client-lawyer relationship with the client [.]" Under a reasonable belief that the client has diminished capacity, "the lawyer may take reasonably protective action [,]" including but not limited to "seeking the appointment of a guardian ad litem, conservator, or guardian." The use of "reasonable" and the vague nature of "protective action" provide substantial deference to the attorney and allows for an array of potentially varied and insufficient representation on behalf of a client with diminished capacity. This is particularly true if an attorney is not aware of the possibility that her client may have diminished capacity.

In determining the existence or extent of a client's potentially diminished capacity, the attorney may consider factors such as the client's ability to articulate reason, and the capability of the client to understand and appreciate the consequences of a decision [46]. However, attorneys are not trained on how to determine whether a client has diminished capacity. Furthermore, an attorney must be vigilant about the possibility that a client has diminished capacity, as a client's apparent understanding of the proceedings may not be as it appears. In addition, it could be difficult for an attorney to understand the possibility that a client has diminished capacity and proceed without proper safeguards.

\section{4) Gerald jones' case study}

From a very young age, Gerald was let down by the system and his family. Shuffled on from grade to grade throughout school, Gerald exhibited warning signs of a serious cognitive impairment from a very young age. However, his cognitive impairment was not addressed by the school or his family even though they either suspected, or were aware of his impairment. Instead, he was diagnosed with Attention Deficit Hyperactive Disorder (ADHD) in the first grade and was prescribed Ritalin. In sixth grade, when his behavior problems continued, Gerald was diagnosed with oppositional defiant disorder and placed in special education programs. Unfortunately, his serious cognitive impairment was still not diagnosed and was ignored by the public school system. As further proof of the "system" letting him down, the Individualized Educational Program (IEP) that was required for the school to have for Gerald was centered on Spanish as Gerald's native language. The problem? Gerald did not speak Spanish.

Gerald's case arose when the county brought a paternity action against Gerald due to the children's mother's acceptance of public assistance. Under Minnesota law, a court appointed attorney is available to parents in paternity matters on the basis of financial need.

Gerald presented very well. It was not apparent to the attorney right away that Gerald lacked capacity to understand 
the proceedings. When you saw and talked to him, you would not think that he was disabled. Additionally, with no prior documentation of any cognitive issue, there were no apparent red flags as to Gerald's competency. Gerald had difficulty explaining why he had done certain things. This, in and of itself, was not unusual as oftentimes clients are unable to explain why they decided to do a certain thing or chose not to do something. However, Gerald seemed to have difficulty explaining a lot of things. He attempted to make it look like the reason why he never had a job was because he was lazy. In fact, Gerald never had a job because he never received any job offers even though he applied at numerous jobs. It was only after multiple conversations that the attorney started to question whether Gerald truly understood what was being discussed. With the ability to project simple verbal and physical cues, Gerald would seemingly understand the basic factual and legal questions being presented before him. However, after a few more simple inquiries into the issues, Gerald's failure to accurately convey what should have been simple answers started to cause concern.

Believing that Gerald did not fully comprehend the situation and was not actually following what was happening in his case, the attorney decided to conduct an experiment. She explained to Gerald the experiment that she was going to conduct, but she did not explain until after the experiment was completed why she was conducting the experiment. She decided to conduct an experiment where she would hold a mock interview with Gerald after he told her that he never had a job because he was not able to "pass" the interview. Within a few brief moments, it became apparent to the attorney that Gerald potentially suffered from cognitive impairments. Concerned for Gerald's well-being, a motion was filed with the court seeking a competency evaluation. The motion was not opposed by the mother or the county's attorney, and the motion was granted.

In feeling as though it was within her duties as the attorney of Gerald, and to ensure his right to due process, she attended the evaluation with Gerald. Exhibiting some of the same responses as she had received from Gerald just weeks before, Gerald was seemingly doing enough to convince the evaluator that he understood what was being asked of him. Having seen this before, the attorney quickly corrected the situation and alerted the evaluator of Gerald's ability to act as though he comprehends, despite not having the ability to do so. Aware of Gerald's skill in acting as though he understood perhaps more than he did, the evaluator was able to accurately assess Gerald's cognitive abilities. To the attorney, the results were unsurprising. Although Gerald was able to make his way through daily tasks, his intelligence level was considered extremely low. Furthermore, the evaluator determined that Gerald was incompetent.

After receiving the results of the competency evaluation, the attorney requested that a well known and experienced guardian ad litem (GAL) with experience working with the developmentally delayed population be assigned to Gerald. Citing budget constraints, the court denied the motion for the experienced GAL, and instead assigned a volunteer GAL. The volunteer GAL must be given due credit for her service. However, perhaps even more than an attorney, the GAL must be familiar and prepared for the challenges and the needs of each of their clients. With the feeling that the court-assigned GAL was more in name than in practice, the attorney was again faced with difficult issues.

In need and eligible for Supplemental Security Income (SSI), Gerald's GAL refused to assist. So the attorney found someone to help Gerald apply for SSI as otherwise Gerald would not have the means to support himself and he would have had to pay child support, which he was financially unable to afford. Gerald's issues did not stop there. Having requested and agreed to a six month provisional parenting time arrangement, Gerald routinely failed to comply with the order. Despite endless attempts to organize rides and make visitation easier, there can only be so much that an attorney can do.

\section{CONCLUSION}

Faced with a number of new legal issues concerning the representation of a potentially incompetent client, attorneys face unfortunately difficult situations. As an attorney, one is responsible to secure the best outcome for his or her client taking into consideration the facts and ethical considerations.

What would the result have been if the attorney had not taken it upon herself to pick up on Gerald's lack of understanding during the initial client meeting? Gerald likely would have continued to fall through society's cracks. Even though Gerald did not have the ability or willingness to follow through with his parenting time order, Gerald now has income through SSI. Furthermore, he does not have to be burdened with paying a child support obligation that he is completely unable to meet. As an attorney, one must be ever vigilant to ensure that a client has the capacity and competency to assist in their case, and when it turns out that a client does not, the attorney has to determine the best route for his or her client. While it is a common duty in the legal community to strip the 'legalese' out of client conversation and to frame the legal issues and terms in a more easily understood fashion for the client, this is not always enough. The attorney cannot simply assume that the client knows, even in the most simple of legal issues, what you, as the attorney, are talking about. Much like dealing with a client who does not understand English, additional steps and precautions must be set out to make sure that the attorney is properly fulfilling their ethical representational duties for their client.

\section{REFERENCES}

[1] V. Sartori, Harnischfeger Corp., 432 N.W.2d 448, 453, "The due process protection provided under the Minnesota Constitution is identical to the due process guaranteed under the Constitution of the United States," 1988.

[2] J. V. Zerbst, 304 U.S. 458, 58 S.Ct. pp. 1019, 1938; Aetna Insurance Co. v. Kennedy, 301 U.S. 389, 393, 57 S.Ct. 809, pp. 811-812, 1937; Ohio Bell Telephone Co. v. Public Utilities Commission, 301 U.S. 292, 307 , 57 S.Ct. 724, 731, 81 L.Ed. pp.1093, 1937.

[3] Rules of Prof. Conduct 1.14, 2012.

[4] United States 2010 Census, "The number of single-parent households has doubled since 1960."

[5] Minnesota Chapters 257 and 518 and Minnesota Chapter 257C.

[6] State ex rel Glasier v Glasier, 272 Minn. 62, 68, 137 N.W.2d 549, pp. 554 1965, "The state of the child's domicile has jurisdiction to determine the custody of the child."

[7] J. Atkinson, Criteria for Deciding Child Custody in the Trial and Appellate Courts, 18 Fam. L.Q. 1, 39, 1984. 
[8] Molto v. Molto, 242 Minn. 112, 114, 64 N.W.2d 154, 156, 1954, MINN. STAT, § 518.17, SUBD. 1, 2012.

[9] P. Pikula, 374, N. W. 2d 705, 710, 1985, Minn. R. Civ. P. 52.01.

[10] J. Atkinson, Criteria for Deciding Child Custody in the Trial and Appellate Courts, 18 FAM. L.Q. no. 1, vol. 39, 1984.

[11] MINN. STAT, § 518.17, 2012, Reno v. Flores, 507 U.S. 292, 304, 1993, Matter of Welfare of J. J. B., 390 N.W. 2d 274, 278-81, Minn. 1986.

[12] MINN. STAT. \&. 518.17, 2012.

[13] R. H. Mnookin, Child Custody Adjudication: Judicial Functions in the Face of Indeterminacy, 39 LAW \& CONTEMP, PROBS. pp. 226, 1975.

[14] Sefkow v. Sefkow, 427 N.W.2d 203, vol. 211, 1988.

[15] MINN. STAT, §. 518.17, subd. 1, 2011, In re Weber, 653 N. W. 2d 804, 809, Minn. App. 2002, MinN. STAT. pp. 518.18, 2012

[16] MINN. STAT, §. 518.17, subd. 2, 2012.

[17] In re Paternity of B. J. H., 573 N.W.2d 99, 102, Minn.App.1998.

[18] H. V. Pogatchnik, 276 N.W.2d 633, 636, Minn.1979.

[19] MINN. STAT, §. 518.17, subdiv. 1, 2012.

[20] MINN. STAT, §. 518.17, subdiv. 1(a), 9, 2012.

[21] MINN. STAT, §. 363A.03, subdiv. 12, 2012.

[22] Compare Schumm v. Schumm, 510 N.W. 2d 13, Minn. Ct. App. 1993, and Meyer v. Meyer, 375 N.W.2d 820, Minn. Ct. 1985.

[23] Schumm v. Schumm, 510 N. W. 2d 13, 14, Minn. Ct. App. 1993.

[24] Schumm v. Schumm, 510 N.W. 2d 13, 15, Minn. Ct. App. 1993.

[25] Meyer v. Meyer, 375 N. W. 2d 820, Minn. Ct. 1985

[26] J. R. Parham v., 442 U.S. 584, 602, 1979.

[27] Universal Declaration of Human Rights art. G.A. Res. 217A. (Dec. 10, 1948) [Online]. 16(3). Available: http://www.unhchr.ch/udhr/lang/eng.htm.

[28] Baldwin v. Hale, 68 U.S. (1 Wall) 223, 233, 17 L.Ed. 531, 1863.

[29] Armstrong v. Manzo, 380 U.S. 545, 85 S.Ct. 1187, 14 L .Ed. 2d 62, 1965.

[30] Troxel v. Granville, 530 U.S. 57, 65, 2000.

[31] Santosky v. Kramer, 455 U.S. 745, 758-59, 102 S.Ct. 1388, 71 L. Ed. 2d 599, 1982.

[32] Stanley v. Illinois, 405 U.S. 645, 92 S. Ct. 1208, 31 L .Ed. 2d 551, 1972.

[33] In Re the Adoption of A. A. T., 196 P. 3d 1180, 1189, Kansas 2008.

[34] In re K.M.H., 285 Kan. 53, 77, 169 P.3d 1025, 2007.
[35] Lehr v. Robertson, 463 U.S. 248, 262, 103 S.Ct. 2985, 77 L. Ed. 2d 614, 1983.

[36] MINN. STAT. § 253B.02, Subd. 13, 2012.

[37] MINN. STAT. §. 253B.09, subd. 5, 2012.

[38] MINN. STAT, §. 518.17, 2012.

[39] MINN. STAT, §. 518.18(d) (iii), 2012.

[40] Dannelley v. Dannelley, 417 S.W. 2d 55, 57, Texas, 1967.

[41] MINN. STAT, 518.17, subd. 1, 9, 2012.

[42] MINN. STAT, §. 363A.03, subd. 12, 2012.

[43] MINN. STAT, §. 518, vol. 17, no. 1, 2, 2012.

[44] Halverson ex rel. Halverson v. Taflin, 617 N.W. 2d 448, 450, Minn. App. 2000, Stanley v. Illinois, 405 U.S. 645, pp. 657-58, 1972.

[45] Rules of Prof. Conduct. 1.1, 2012.

[46] 52 M. S. A., Rules of Prof. Conduct, Rule 1.1.4 editor's note 6, 2012.

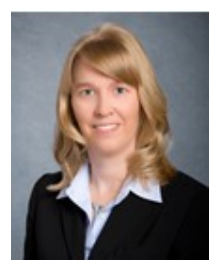

Evon M. Spangler is an attorney and founding partner of Spangler and de Stefano, PLLP. She has a Juris Doctorate from William Mitchell College of Law, St. Paul, Minnesota, United States of America, where she graduated cum laude in 1998 .

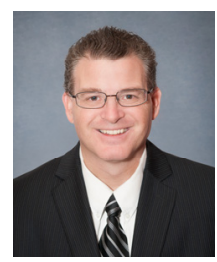

Perry M. de Stefano is an attorney and founding partner of Spangler and de Stefano, PLLP. He has a Juris Doctorate from Thomas M. Cooley Law School, Lansing, Michigan, United States of America, where he graduated in 1995. 